\title{
Lugemisstrateegiate kasutus akadeemilises õppes
}

\author{
TIINA KIKERPILL \\ Tartu Ülikool
}

Ülevaade. Artikkel käsitleb lugemist eesti keeles emakeelena ja teise keelena ülikooliõpingute kontekstis. Uurimuse eesmärk oli välja selgitada, missuguseid strateegiaid üliõpilased enese hinnangul kasutavad õppeülesannete täitmiseks vajalike tekstide lugemisel eesti keeles ning missuguseid teksti mõistmise raskusi nad seejuures teadvustavad. 80 Tartu Ülikooli eesti ja muu emakeelega üliõpilast 27 erialalt täitsid küsimustiku, millega kogutud andmeid analüüsiti nii emakeelest kui ka õppeastmest lähtuvalt. Tulemused näitasid, et 1) üliõpilased on eesmärgipärased ja teksti üksikasjadesse süüvivad lugejad; 2) emakeel mõjutab lugemist nõudva ülesande täitmise kiirust ja tundmatute sõnadega tegelemise viisi; 3) taustteadmised on teksti mõistmisel olulisel kohal sõltumata emakeelest ja õppeastmest.

Võtmesõnad: lugemisoskus; teksti mõistmine; metakognitsioon; lugemisstrateegiad; lugemine akadeemilises õppes; teine keel; eesti keel

\section{Sissejuhatus}

Tekstide lugemine on õppetöös kesksel kohal ning nende mõistmise ulatusest ja täpsusest sõltub teadmiste ja oskuste omandamine. Kuigi akadeemilises õppes on ühtviisi tähtis aru saada nii suulistest (loengud, diskussioonid) kui ka kirjalikest tekstidest, hangitakse enamik erialateabest siiski kirjalike tekstide kaudu. 
Missuguseid tekste ja mis eesmärgil üliõpilased lugema peavad, sõltub õpitavast erialast, õppeastmest ja konkreetsest ainekursusest. Mõnede Tartu Ülikooli õppekavade õpiväljundites ${ }^{1}$ on eesmärgid sõnastatud muu hulgas ka erialaste tekstide mõistmise kohta. Näiteks sotsiaalteaduste valdkonna psühholoogia õppekava bakalaureuseõppe läbinud üliõpilane "oskab kriitiliselt lugeda ja analüüsida psühholoogia originaaltekste, uurimistulemusi ja projekte ning oskab eristada tõenduspõhist teadmist emotsionaalsest arvamusest"; humanitaarteaduste ja kunstide valdkonna ajaloo magistriõppekava läbinu "tunneb oma erialaga seotud allikaid ja historiograafiat ning oskab analüüsida erinevaid historiograafilisi seisukohti". Teksti mõistmine ei kajastu eksplitsiitselt meditsiiniteaduste valdkonna õppekavade õpiväljundites, kuid võib oletada, et see on eelduseks produktiivsetele oskustele "ennast erialaselt väljendada" ning teha teadustööd.

Lugemist akadeemilises õppes (ingl academic reading) iseloomustab orienteeritus produktiivsele väljundile (Jordan 1997; Taraban jt 2004). See tähendab, et erialaõpingutes loetakse erinevaid tekste enamasti selleks, et täita mingeid suulisi või kirjalikke õppeülesandeid nagu referaadi, seminaritöö või lõputöö koostamine ja kaitsmine, seminariarutelus osalemine, kaasüliõpilase töö retsenseerimine jm. Ülesanne annab lugemisele eesmärgi, mille põhjal üliõpilane otsustab, kuidas ta tekstiga töötab.

Kahtlemata areneb akadeemiline keelekasutus, sh lugemisoskus erinevate ainekursuste õppeülesandeid täites, kuid uurimused kinnitavad, et erialaste tekstide mõistmine tekitab raskusi nii emakeeles (K1) kui ka teises keeles (K2) õppimisel (Weir jt 2000) ning sellele peaks ülikoolis eraldi tähelepanu pöörama eriti kõrgkooliõpingute alguses (Hermida 2009).

Ka Eestis läbi viidud uuringute tulemused on näidanud, et gümnaasiumis omandatud eesti keele oskus ei ole kõigis aspektides kõrgkooliõpinguteks piisav olenemata sellest, kas õpitakse emakeeles või teises keeles. Martin Ehala jt $(2010 ; 2015)$ uurisid ülikoolide esimese aasta

1 Õppekavad on leitavad otsinguga TÜ õppeinfosüsteemist https://www.is.ut.ee/ pls/ois/tere.tulemast > õppekavad. 
eesti emakeelega üliõpilaste eesti keele oskust, mille tulemusena tehti ettepanekuid eesti keele õppe tõhustamiseks gümnaasiumis. Üks testiga kontrollitud oskus oli mittelineaarse teksti mõistmine, milles saavutas akadeemiliseks õppeks piisava tulemuse 2010. aasta uuringus 19\% ja 2015. aasta kordusuuringus 17,1\% ülesande täitnud üliõpilastest. Kuna joonistel ja tabelites esitatud teave on lahutamatu osa teadustekstist, võivad uuringute tulemused osutada puudustele teadusteksti mõistmises üldiselt.

Viimasel ajal on hakatud tähelepanu pöörama ka ülikoolides eestikeelsetel õppekavadel õppivatele mitte-eestlastele, kellel võib eriala omandamist raskendada ebapiisav keeleoskustase. Helena Metslang ja Anastassia Šmõreitšik (2012) uurisid K2 üliõpilaste keelelist toimetulekut akadeemilises õppes, et välja selgitada nende vajadusi. Lugemisoskuse kohta selgus uuringust, et üliõpilased ei ole rahul keelekursustel lugemisoskuse arendamiseks kasutatava metoodikaga, kuid samas ei teadvusta nad teksti mõistmise olulisust erialaõpingutes. Seda näitas nende madal hinnang vajadusele arendada teksti mõistmise oskusi erialase eesti keele kursusel, mis on ülikoolides pakutav peamine tugi mitte-eesti üliõpilastele. (Metslang \& Šmõreitšik 2012: 28-35)

Selleks, et kujuneksid süsteemsed teadmised oma eriala valdkonnas, peab lugeja kasutama teksti mõistmise kõrgema tasandi protsesse (vt nt Khalifa \& Weir 2009; Grabe 2009; Rapp jt 2007), mille käigus luuakse seoseid varasemate teadmistega, teiste tekstidega ning kujuneb üksikasjalik ja terviklik arusaam loetust. Muu hulgas nõuavad ülikooliõpingud ulatuslike ja keerukate tekstide kiiret, valikulist ja tõhusat lugemist (Urquhart \& Weir 1998), et näiteks otsustada nende sobivuse üle mingi ülesande täitmiseks. Kas üliõpilane on ka oskuslik lugeja, sõltub paljuski tema metakognitiivsest teadlikkusest töös tekstidega: oskusest oma lugemistegevust eesmärgistada, kontrollida, märgata teksti mõistmisel ette tulevaid takistusi ja valida nende ületamiseks sobivaid strateegiaid (Cromley \& Wills 2016).

Eestis on uuritud kooliõpilaste lugemisoskust ja -harjumusi (vt nt Uibu \& Männamaa 2014; Soodla \& Kikas 2014; Puksand 2010), kuid 
lugemist akadeemilises õppes ei ole käesoleva artikli autori andmetel Eestis seni uuritud.

Siinses artiklis tutvustatakse uurimust, mis käsitleb lugemist eesti keeles emakeelena ja teise keelena ülikooliõpingute kontekstis. Et paremini mõista üliõpilast kui lugejat ja välja selgitada, kas ja missugust tuge ta vajaks, püstitati järgmised uurimisküsimused: 1) missuguseid lugemisstrateegiaid üliõpilased enese hinnangul kasutavad õppeülesannete täitmiseks vajalike tekstide lugemisel, 2) missuguseid raskusi üliõpilased töös tekstidega tajuvad ning 3) mil määral erinevad strateegiakasutus ja tajutavad raskused eesti ja mitte-eesti emakeelega üliõpilastel ning bakalaureuse- ja magistriüliõpilastel. Et saada ülevaade üldisest kontekstist, milles täidetakse lugemist nõudvaid ülesandeid, uuriti ka, missuguseid tekste loetakse ja kui suur on üliõpilaste hinnangul eestikeelsete tekstide osakaal.

\section{Lugemine akadeemilises õppes}

Tekstide lugemine on ülikooliõpingutes erialase teabe hankimise põhitegevus, mida mõjutavad paljud õppimise ja õppijaga seotud tegurid. Siinses peatükis on vaatluse all peamiselt teksti mõistmisega ja keeleoskusega seotud aspektid, et luua taust uurimistulemuste tõlgendamiseks. Esimene alapeatükk selgitab teksti mõistmise olemust ja lugemisstrateegiate kui uurimuse objekti seoseid lugemisprotsessiga; teises alapeatükis tutvustatakse lugemisstrateegiate uurimise meetodeid ja üliõpilaste seas läbi viidud uurimusi.

\subsection{Teksti mõistmine ja lugemisstrateegiad}

Lugemisoskuse seletamiseks on loodud erinevaid teooriaid (vt ülevaateid nt Nassaji 2014; Grabe 2009: 91-106; McNamara \& Magliano 2009). Käesoleval ajal valitseb seisukoht, et teksti mõistmine on interaktiivne protsess ning selles eristatakse kognitiivseid ja metakognitiivseid komponente, mis koostöös mäluprotsessidega ja neis aktiveeritavate erinevate 
teadmistega osalevad lingvistilise teabe töötlemises ja tähenduse loomises (Nassaji 2014; Grabe 2009; Khalifa \& Weir 2009). Määratlus laieneb nii emakeeles kui ka teises keeles lugemisele, mille protsessides uurijad olulisi erinevusi ei näe (Alderson 1984; van Gelderen jt 2004; Khalifa \& Weir 2009), mistõttu lähtub sellest ka käesolev uurimus.

Kuigi teksti mõistmise protsess emakeeles ja teises keeles on sarnane, on siiski rida tegureid, mille poolest K1 ja K2 lugemine erinevad. Näiteks toimub emakeeles lugema õppimine üldjuhul varases eas ja järgneb suulise keele omandamisele, samas kui K2 lugemine on enamasti seotud teise keele õppimisega (Nassaji 2014: 5). Teksti mõistmist teises keeles lugemisel mõjutab K1 ja K2 lingvistiline distants (Han 2015; Grabe 2009; Koda 2004), aga ka lugeja kultuuritaust ja sihtkultuuri tundmine (Grabe 2009: 138-139). Samuti on teises keeles lugemine alati mõjutatud emakeeles omandatud oskustest, millest tuleb juttu allpool.

Lugemisoskuse kognitiivsed komponendid (ingl cognitive skills, cognitive processes), nagu morfosüntaktilise info töötlemine või tervikliku ettekujutuse loomine loetust, on otseselt suunatud teksti mõistmisele ning need võivad olla lugejale kas teadvustatud või teadvustamata. Kui loetav tekst on jõukohane, ei teadvusta lugeja tähenduse mõistmisse kaasatud mentaalseid tegevusi, sest tegemist on automaatseks kujunenud oskusega. Kui aga teksti mõistmine valmistab näiteks täidetava ülesande tõttu lugejale mingis osas raskusi ja nende ületamiseks on vaja välja selgitada kas sõnade tähendusi, terminitega väljendatud mõistete olemust või tuleb puuduvate taustteadmiste kompenseerimiseks koguni lisaks lugeda, teadvustab lugeja teksti mõistmise raskusi ja nende põhjusi. (Grabe 2009: 222-225)

Kognitiivsetes tegevustes eristatakse teksti mõistmise madalamat ja kõrgemat tasandit (ingl vastavalt lower-level processes, higher-level processes, ka bottom-up processes, top-down processes) (vt nt Grabe 2009; Khalifa \& Weir 2009), mille osiseid ühendab töömälu. Madalamal tasandil (vt Nassaji 2014) töödeldakse lingvistilist teavet sõna-, fraasi- ja lausetasandil nii vormi kui ka tähenduse mõistmiseks. Üks selle tasandi mentaalne tegevus, mida on uuritud nii K1 kui ka K2 lugemises, on 
sõnatuvastus (ingl word recognition) (vt ülevaadet Han 2015). Uurimuste kohaselt on sõnatuvastus ja selle kiirus (automaatsus) teksti mõistmise üks tugevamaid indikaatoreid nii emakeeles kui ka teises keeles lugemisel (Nassaji 2014: 6-7). Kõrgema tasandi komponentideks peetakse n-ö lugejast lähtuvaid tegevusi, mille käigus toimub tekstiga otseselt väljendatud tähenduse ehk tekstibaasi (ingl text base, text model, propositional meaning) loomine, loetu seostamine erinevate taustteadmistega ning kujuneb terviklik arusaamine loetud tekstist või tekstidest ehk situatsioonimudel (ingl situation model, mental model). (Kintsch 1988; Khalifa \& Weir 2009: 50-52; Grabe 2009: 40-43)

Taustteadmiste hulka kuuluvad nii teemakohased kui ka üldteadmised, kuid nendeks võib pidada ka teadmisi teksti tüübist ja liigist ning varasemaid kogemusi sarnaste tekstide lugemisel (Grabe 2009: 73-76; Rapp jt 2007). Sõltuvalt sellest, mida täpsemalt taustteadmiste all silmas on peetud, on uurimused andnud erinevaid tulemusi nende osatähtsuse kohta teksti mõistmisel. Näiteks moodustas taustteadmiste osakaal teksti mõistmisest $16-23 \%$, kui nendena käsitleti erialaspetsiifilisi teadmisi (Taboada \& Guthrie 2006).

Kui lugemisoskuse kognitiivsed komponendid on seotud teksti töötlemisega mentaalsetes protsessides, siis metakognitiivsed tegevused (ingl metacognitive skills, metacognitive strategies) väljenduvad erinevate lugemist hõlbustavate võtete kasutuses ja iseloomustavad lugejat, näidates, kas ja kuidas ta eesmärgistab, suunab ja kontrollib oma tegevust. Teksti mõistmise metakognitiivsed tegevused on valdavalt teadvustatud, kuid lugemisoskuse mõõtmise vallas on leitud, et edukamatel testisooritajatel on metakognitiivsete strateegiate kasutus automaatsem kui vähem edukatel (Phakiti 2003; Alderson 2000).

Metakognitsioon seostub seega lugemistegevuse strateegilise poolega, mille puhul ollakse seisukohal, et emakeeles omandatud oskused kanduvad ka teises keeles lugemisse (Grabe 2009; Kong 2006; Koda 2004; Alderson 2000). Nimetatud ülekanne on olnud kesksel kohal K1 ja K2 lugemise omavaheliste seoste uurimisel ning palju tähelepanu on pälvinud lingvistilise lävendi hüpotees (ingl linguistic threshold hypothesis, 
language threshold hypothesis) mille kohaselt emakeeles omandatud oskuste ülekanne on võimalik vaid siis, kui teise keele lingvistilised teadmised (grammatika- ja sõnavara valdamine) on jõudnud teatud tasemeni (Grabe 2009: 146-148; Alderson 2000: 39).

Charles Aldersoni (1984) püstitatud küsimusele, kas probleemid teises keeles lugemisel tulenevad emakeeles lugemise oskusest või teise keele puudulikust lingvistilisest pädevusest (Alderson 1984), on aastate jooksul otsitud vastust paljudes uurimustes (vt nt Bernhardt \& Kamil 1995; Bialystok jt 2005; Walter 2007; Jeon \& Yamashita 2014). Hiljutine metaanalüüs (Jeon \& Yamashita 2014) andis Aldersoni küsimusele vastuseks, et probleemid K2 lugemisel näivad olevat põhjustatud pigem K2 keeleteadmistest (grammatika, sõnavara), kuid oma osa on ka metakognitiivsetel teguritel.

Nagu öeldud, võib teksti mõistmise kognitiivseid ja metakognitiivseid tegevusi vaadelda lugemistegevuste teadvustatuse aspektist. Teadvustatud tegevusi käsitletakse kui strateegiaid, mille kasutamist lugeja kontrollib, samas kui teadvustamata tegevused on automaatseks kujunenud oskused, mida lugeja kasutab alateadlikult (Grabe 2009: 220-242). Niisugune lähenemisviis aitab lahendada lugemise uurijate sagedast küsimust, kus lõpevad kognitiivsed tegevused ja algab metakognitsioon (Bax 2013). Samuti on selle kaudu võimalik seletada lugemisstrateegiate olemust.

Lugemisstrateegiaid (ingl reading strategies), mis on käesoleva uurimuse keskmes, võib seega defineerida kui lugemisel teadlikult kasutatavaid kognitiivseid ja metakognitiivseid tegevusi, mis hõlbustavad teksti mõistmist ja aitavad lugemisega seotud eesmärki täita (Khalifa \& Weir 2009; Cohen 2006; Phakiti 2003).

Uurimustes on strateegiaid erinevalt liigitatud (vt nt Kikerpill 2012; Sheorey \& Mokhtari 2001; Cromley \& Wills 2016) ja lugemisstrateegia mõistetki on mitmeti tõlgendatud. Vahest kõige levinum on olnud arusaam, et lugemisstrateegiad on kolm või neli erinevat võimalust teksti lugeda: üld-, valik- ja süvalugemine (ka globaalne, selektiivne ja detailne lugemine), tihti ka loovlugemine. Väga sageli kohtab 
keeleõppemetoodilisi materjale, milles lugemisstrateegiateks peetakse hoopis lugemisoskust arendavaid mitmesuguseid õppetegevusi.

Uurijad on püüdnud lugemisstrateegiate erinevates käsitlustes selgust luua ning selles võib pöördeliseks pidada Alexander Urquharti ja Cyril Weiri (1998) lugemistüüpide (ingl reading type) maatriksit, mis andis varem levinud arusaamale lugemisstrateegiatest uue tähenduse. Nad eristasid kahte tüüpi lugemist (vt tabel 1), mida lugeja sõltuvalt eesmärgist rakendab kas tekstile tervikuna (nt põhisisu mõistmiseks) või selle mingi(te)le osa(de)le, nt lause täpseks mõistmiseks.

TABEL 1. Lugemistü̈̈pide maatriks (Urquhart \& Weir 1998)

\begin{tabular}{|c|c|c|c|}
\hline \multirow{2}{*}{ :ڤٌ } & Süvalugemine & Globaalne tasand (kogu tekst) & \multirow{2}{*}{ 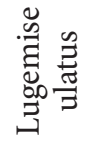 } \\
\hline & Silmav lugemine & Lokaalne tasand (tekstiosa) & \\
\hline
\end{tabular}

Süvalugemine (ingl careful reading) on olemuselt üksikasjadesse ja seostesse süvenev, silmav lugemine (ingl expeditious reading) on seevastu kiire ja valikuline või otsiv lugemine mingi konkreetse teabe leidmiseks või tekstist ülevaate saamiseks (Weir jt 2012: 39-48; Krishnan 2010). Akadeemilises õppes on nende kasutamine sõltuvuses eelkõige õppeülesandest, kuid on leitud, et just silmava ja tõhusa lugemise oskus eristab emakeeles ja teises keeles lugejaid. Viimastele on teabe kiire leidmine tekstist valmistanud raskusi (Weir jt 2000: 16; Bax 2013: 17). Urquharti ja Weiri (1998) lugemistüüpide maatriksi kaasasid Khalifa ja Weir (2009) teksti mõistmise protsessi kirjeldamisse laiemalt, esitades oma mudeli lugemisest. Viimast on kasutatud nii lugemisstrateegiate uurimiseks akadeemilises õppes (Weir jt 2012; Krishnan 2010) kui ka lugemistesti kognitiivse valiidsuse uurimisel (Bax 2013; Kikerpill 2012).

Khalifa ja Weiri (2009) mudel peegeldab nüüdseks levinud arusaama, et lugemistüübid moodustavad vaid osa lugeja metakognitiivsetest tegevustest ning et lugemisstrateegiaidki ei ole võimalik lõpliku loendina esitada, nagu seda varem püüti teha. Neis kombineeruvad 
erinevad lugemistegevused, mida mõjutavad nii teksti, ülesande kui ka lugeja karakteristikud. Näiteks käesoleva uurimuse küsimustiku strateegias loen teksti detailselt, et üksikasjadest täpselt aru saada (vt lisa 1) sisaldub nii teadlikult valitud lähenemisviis tekstile (lugemistüüp) kui ka lugemise eesmärk. Eristatakse teksti mõistmise seisukohast rohkem ja vähem efektiivseid lugemisstrateegiaid, mille kasutuse põhjal saab otsustada, kui oskusliku lugejaga on tegemist. Nii on teksti edukamat mõistjat iseloomustatud kui paindliku strateegiakasutusega lugejat, kes valib mingi takistuse ületamiseks sõltuvalt olukorrast erinevaid võtteid, samas kui nõrgem lugeja kasutab järjekindlalt ühte strateegiat (Cromley \& Wills 2016: 53).

Käesolevas uurimuses ei ole strateegiate liigitamine olnud eesmärgiks, kuid analüüsimisel on lähtutud Khalifa ja Weiri (2009: 43) teksti mõistmise mudelist ning selles sisalduvast lugemistüüpide maatriksist.

\subsection{Lugemisstrateegiate uurimisest}

Teksti mõistmist saab uurida nii tulemusest (ingl product) kui ka protsessist lähtuvalt (vt Weir jt 2000: 15). Esimesel juhul on tähelepanu sellel, missuguse tulemuseni lugeja jõuab teksti mingil eesmärgil lugedes, näiteks tekstiga kaasnevatele küsimustele vastates. Teisel juhul on vaatluse all protsess ehk kognitiivsed ja metakognitiivsed tegevused, mille abil lugeja teksti mõistmiseni jõuab. Lugemisstrateegiate puhul on tegemist protsessi uurimisega, milleks sõltuvalt eesmärgist võib kasutada erinevaid meetodeid.

Üks meetod üliõpilaste lugemistegevusi uurida on olnud nende küsitlemine. Küsitlemine on sobiv meetod käitumise ja tegevuste uurimiseks ning andmete kogumiseks suuremalt valimilt (Hirsjärvi jt 2005). Seetõttu on mõistetav, et lugemisstrateegiate kui teadvustatud lugemiskäitumise uurimiseks on välja töötatud erinevaid küsimustikke (vt Weir jt 2012; Sheorey \& Mokhtari 2001; Hellekjær 2009; Taraban jt 2004). Küsitluse üheks puuduseks peetakse küsimuste erineva tõlgendamise võimalust (Hirsjärvi jt 2005: 182), mis lugemisstrateegiate komplekssust 
arvestades võib küsitletavale probleemiks osutuda. Siin võib abiks olla kontrollitud küsitluse (Hirsjärvi jt 2005: 183-184) kasutamine, mille puhul andmekoguja jagab ankeedid küsitletavatele isiklikult, informeerides neid täitmise üksikasjadest ja vastates tekkivatele küsimustele. Andmete usaldusväärsust mõjutab ka see, kui ausad on antavad vastused. Eriti oma lugemisraskusi hinnates võib küsitletav tahta oma raskusi varjata.

Cyril Weir jt (2012) kogusid küsitlusega andmeid 764 üliõpilase lugemiskäitumise kohta eesmärgiga täpsustada IELTS ${ }^{2}$ akadeemilise testi lugemise osa mõõdetavaid oskusi. Sama uuringu raames valmis doktoritöö (Krishnan 2010), mis keskendus esimese aasta üliõpilaste lugemistegevuste uurimisele fookusega lugemistüüpide kasutamisel. Tulemuste põhjal järeldati, et Urquharti ja Weiri (1998) lugemistüüpide maatriks sobib esimese aasta üliõpilaste lugemistegevuste kirjeldamiseks.

Ravi Sheorey ja Kouider Mokhtari (2001) on küsitlenud 302 inglise keelt esimese ja teise keelena kõnelevat üliõpilast, uurides nende toimetulekut lugemist nõudvate õppeülesannetega. Lugemisstrateegiaid vaadeldi kolmes kategoorias: kognitiivsed, metakognitiivsed ja tugistrateegiad. Viimaste hulka loeti abimaterjalide kasutamist, olulise allajoonimist, märkmete tegemist, teksti ülelugemist. K1 ja K2 rühma andmete võrdlus näitas, et mõlemas rühmas oli strateegiakasutus sagedasem nendel, kes oma inglise keeles lugemise oskust olid hinnanud kõrgeks. Tugistrateegiaid kasutasid sagedamini K2 üliõpilased ja K1 rühma kõrge lugemisoskusega üliõpilased. (Sheorey \& Mokhtari 2001)

Lisaks küsitlemisele kasutatakse lugemisstrateegiate uurimiseks ka enesevaatluse meetodeid nagu introspektsioon (ingl introspection, think aloud protocol, verbal protocol) ja retrospektsioon (vt lähemalt Kikerpill 2012), mida sageli ka kombineeritakse. Introspektsiooni korral verbaliseeritakse oma mõtteid ja otsustusi ülesande täitmise käigus, retrospektsiooniga kogutakse andmeid pärast ülesande täitmist. Need võimaldavad uurida vähem teadvustatud lugemistegevusi, kuid meetodist tulenevalt on valimi suurus võrreldes küsitlemisega piiratud, ulatudes harva üle

\footnotetext{
2 International English Language Testing System. http://takeielts.britishcouncil. org/prepare-test/understand-test-format (27.9.2017).
} 
kümne. Samuti tuleb arvestada, et introspektiivsete andmete kogumiseks optimaalne aeg on umbes üks tund. Jennifer Cromley ja Theodore Wills (2016) kasutasid introspektsiooni, et uurida lugemisstrateegiate omavahelisi seoseid ja üleminekuid ühelt tegevuselt teisele. Strateegiaid vaadeldi jaotatuna madalama ja kõrgema tasandi tegevusteks lähtuvalt kognitiivsest raskusest. Esimesse rühma arvati nt ülelugemine ja olulise äramärkimine tekstis ning teise rühma nt kokkuvõtte või märkmete tegemine. 24 üliõpilast lugesid erialakursusel kasutatava õpiku teksti nii, nagu nad seda tavaliselt teevad (nt markeerides tekstis olulist). Tulemustest selgus, et need, kes lugemise käigus rohkem õppisid, kasutasid teksti mõistmiseks järeldamist, taustteadmisi ja sõnatundmist enam kui need, kes tekstist vähem omandasid. (Cromley \& Wills 2016)

Kombineeritud meetodit on kasutanud Ivar Bråten ja Helge Strømsø (2003), kelle introspektiivses pikiuurimuses oli vaatluse all lugemisstrateegiate spontaanne kasutus seletavate (ingl expository) erialatekstide lugemisel. Seitse juuraüliõpilast lugesid kolme sessiooni jooksul tsiviilõiguse kursuse õppetööks vajalikke tekste ning verbaliseerisid lugemise käigus oma mõtteid ja otsustusi, mis salvestati. Täiendavaid andmeid koguti ka intervjuudega. Tekstide lugemise eesmärk oli alguses loengutel käsitletud teemade mõistmine ning hiljem eksamiks kordamine. Selgus, et kursuse eksamil kõrgeima tulemuse saanud üliõpilased töötasid tekstiga põhjalikult juba esimesel lugemisel ja olid lugedes kasutanud rohkem teksti mõistmise strateegiaid (nt seostamine taustteadmistega ja varem loetud tekstidega) ja metakognitiivseid tegevusi (nt info korrastamine) ning vähem meeldejätmise strateegiaid. Madalama tulemuse saanud üliõpilased seevastu olid esimesel lugemisel lähenenud tekstile pindmiselt, ignoreerides mõistmisraskusi. (Bråten \& Strømsø 2003)

Steven Bax (2013) uuris IELTS akadeemilise testi lugemisosa kognitiivset valiidsust, kasutades silmaliigutuste jälgimist (ingl eye-tracking) kombineerituna küsitlemise ja retrospektsiooniga ning analüüsides selle kaudu lugemisoskuse kognitiivseid aspekte. Uurimus näitas muu hulgas, et madalama tulemusega testisooritajad ei suutnud tugevamate rühmaga võrreldes kasutada valiklugemist kiiresti ja tulemuslikult vastuse 
seisukohast õige tekstiosa tuvastamisel. Samuti selgus, et silmaliigutuste jälgimine võimaldas poolte üksikküsimuste puhul eristada tugevamaid testisooritajaid nõrgematest, kuid ainult keeletöötluse madalamal tasandil. (Bax 2013)

\section{Uurimuse metoodika}

Et saada ülevaade üliõpilaste hinnangutest oma lugemistegevustele ja -raskustele, on käesolevas uurimuses kasutatud andmekogumismeetodina küsitlemist kui sobivat meetodit teadvustatud protsesside uurimiseks. Andmeid koguti 5-pallise Likerti tüüpi skaala küsimustikuga, mis koosneb neljast osast:

1) küsimused uurimuses osaleja taustandmete kohta;

2) küsimused lugemismaterjali ja lugemisviisi kohta (vastused skaalal 1-5), mille eesmärk on täpsustada konteksti, milles üliõpilased lugemist nõudvaid õppeülesandeid täidavad;

3) küsimused õppeülesannete täitmisel kasutatavate lugemisstrateegiate kohta (vastused skaalal 1-5), mis võimaldab iseloomustada üliõpilast kui lugejat;

4) küsimused õppeülesannete täitmisel tajutavate lugemisraskuste kohta (vastused skaalal 1-5), mis aitab välja selgitada, missugust tuge üliõpilased võiksid vajada töös akadeemiliste tekstidega.

Küsimustiku koostamisel võeti aluseks Weiri jt (2012: 37-119) välja töötatud küsimustik eelkõige selle teoreetiliste seisukohtade sobivuse tõttu. Teine põhjus lähtuda nimetatud uurimusest on võimalus statistilisi tulemusi võrrelda.

Andmeid kogus siinse artikli autor kontrollitud küsitlusega 2016. aasta detsembris Tartu Ülikoolis. Eesmärk oli kaasata erinevate erialade üliõpilasi, kuid samas pidid valimisse kuuluma nii bakalaureuse- kui ka magistriõppe üliõpilased ning nii eesti kui ka mitte-eesti emakeelega üliõpilased. Seetõttu koguti andmeid keelekursustelt (6 rühma), mille osalejaskond on nii erialasid, õppeastmeid kui ka emakeelt silmas pidades kõige mitmekesisem. Üldjuhul toimus küsitlemine loengu lõpuosas, et 
lahkuda saaksid need, kes ei soovinud osaleda. Keelekursuste väiksemad rühmad võimaldasid saada üliõpilastega usaldusliku kontakti, sellele aitas kaasa ka kursuse õppejõudude toetav suhtumine, mis kokku võis suurendada küsitletute soovi vastata ausalt.

Küsimustiku täitmisele eelnesid selgitused, kuid küsimuste tekkimise korral oli üliõpilastel võimalik lisaselgitusi saada. Küsimustiku täitmiseks kulus 10-15 minutit.

Andmed sisestati vabavara programmi PSPP ja analüüsiti nii kvalitatiivselt kui ka kirjeldavat statistikat kasutades.

24 lugemisstrateegia ja 16 lugemisraskuse analüüsimiseks selgitati kogu valimis välja alati ja sageli (skaalal vastavalt 5 ja 4 ) kasutatavate strateegiate ja raskuste sagedused ning andmeid analüüsiti risttabeleid kasutades emakeelest ja õppeastmest lähtuvalt. Sarnaste küsimuste korral on käesoleva uurimuse statistilisi tulemusi võrreldud Weiri jt (2012) tulemustega. Võrreldavuse eesmärgil on sagedusarvud esitatud protsentides.

Uurimuse andmed pärinevad 80 üliõpilaselt, kes küsitlemise hetkel õppisid kokku 27 erialal päevaõppes. Enamus vastanutest (92,5\%) olid nooremad kui 30 aastat. Vastanute hulgas oli 49 (61\%) eesti ja 31 (39\%) muu emakeelega üliõpilast, viimaste enamuse moodustavad vene emakeelega üliõpilased. Muudest emakeeltest on esindatud läti (1), poola (1), inglise (1) ja aserbaidžaani (1) keel. Bakalaureuseõppes või integreeritud õppe 1.-3. aastal õppis 43 ning magistriõppes või integreeritud óppe 4.-5. aastal 37 üliõpilast (vt tabel 2).

TABEL 2. Küsitletute arvuline jaotus emakeele, soo ja óppeaastate järgi

\begin{tabular}{|l|c|c|c|c|c|c|c|}
\hline \multirow{2}{*}{$\begin{array}{c}\text { Õppe- } \\
\text { aasta }\end{array}$} & \multicolumn{4}{|c|}{ Emakeel } & \multicolumn{3}{c|}{ Sugu } \\
\cline { 2 - 8 } & Eesti keel & Vene keel & Muu & Kokku & Mees & Naine & Kokku \\
\hline 1. & 10 & 1 & 0 & 11 & 2 & 9 & 11 \\
\hline 2. & 6 & 8 & 0 & 14 & 4 & 10 & 14 \\
\hline 3. & 7 & 8 & 3 & 18 & 7 & 11 & 18 \\
\hline 4. & 22 & 9 & 0 & 31 & 9 & 22 & 31 \\
\hline 5. & 4 & 1 & 1 & 6 & 2 & 4 & 6 \\
\hline Kokku & 49 & 27 & 4 & 80 & 24 & 56 & 80 \\
\hline
\end{tabular}




\section{4. Üliõpilased akadeemilise teksti lugejana}

Siinses peatükis analüüsitakse küsimustikuga kogutud andmeid õppijate emakeelest ja õppeaastast lähtuvalt. Sageduste koondtabelid strateegiakasutuse ja tunnetatud lugemisraskuste kohta on esitatud lisades 1 ja 2. Näited üliõpilaste vastustest ja täiendavatest kommentaaridest esitatakse muutmata sõnastuses numereerimata plokkidena, näite järel sulgudes olev kood (nt id7) viitab uurimuses osaleja kohale andmekogus.

\section{1. Õppeülesannete täitmiseks vajalik lugemismaterjal}

Küsimustiku teine osa suunas üliõpilasi mõtlema lugemist nõudvate õppeülesannete täitmisele (nt valmistumine seminariaruteluks või eksamiks; essee, referaadi, üliõpilasuurimuse koostamine) ning hindama, 1) kui sageli on õppeülesannete täitmiseks vaja lugeda loetletud allikaid, 2) kui suures mahus loetakse tekste nutiseadmes või arvutiekraanilt, 3) eestikeelse lugemismaterjali osakaalu.

TABEL 3. Opppeülesannete täitmiseks kasutatavate tekstide allikad (\%, väga sageli + sageli)

\begin{tabular}{|c|c|c|c|c|}
\hline Allikas & $\begin{array}{c}\mathrm{K} 1 \\
(\mathrm{~N}=49)\end{array}$ & $\begin{array}{c}\mathrm{K} 2 \\
(\mathrm{~N}=31)\end{array}$ & $\begin{array}{l}1 .-3 . \tilde{\text { oaa }} \\
(\mathrm{N}=43)\end{array}$ & $\begin{array}{l}\text { 4.-5. õa } \\
(\mathrm{N}=37)\end{array}$ \\
\hline Õpikud ja käsiraamatud & $55,1(1)$. & $77,4(2)$. & $65,1(2)$. & $62,2(1)$. \\
\hline Teadusartiklid (üks uurimus) ${ }^{3}$ & $53,1(2)$. & 64,5 (3.) & $65,1(2)$. & $48,6(3)$. \\
\hline Ülevaateartiklid ${ }^{4}$ & 46,9 & 48,4 & $53,3(3)$. & 40,5 \\
\hline Monograafiad $^{5}$ & 2,0 & 6,5 & 0,0 & 8,1 \\
\hline Bakalaureuse- ja magistritööd & 2,0 & 6,5 & 0,0 & 8,1 \\
\hline Veebilehed & $51,0(3)$. & 87,1 (1.) & $72,0(1)$. & $56,7(2)$. \\
\hline Ajalehed & 2,0 & 12,9 & 11,6 & 0,0 \\
\hline
\end{tabular}

3 Küsitluse sõnastus oli “Teadusartiklid (ajakirjadest või artiklikogumikest), mis tutvustavad üht konkreetset uurimust".

$4 \quad$ Küsitluse sõnastus oli "Teadusartiklid (ajakirjadest või artiklikogumikest), mis annavad ülevaate mingi valdkonna uurimisest pikema aja jooksul".

5 Küsitluse sõnastus oli "Mahukamad uurimused (doktoritööd, monograafiad)". 
Õppeülesannete täitmiseks kasutatavaid allikaid hinnati viiepallisel skaalal (5 - väga sageli, 4 - sageli, 3 - mõnikord, 2 - harva, 1 - väga harva). Tabel 3 esitab allikate kasutuse sageduse emakeele ja õppeastme järgi. Sagedusarvude järel sulgudes on märgitud allika koht pingereas.

Internet on küsitluse andmetel kõige sagedamini kasutatav tekstide allikas mitte-eesti emakeelega üliõpilaste ja bakalaureuseõppe üliõpilaste hulgas. K1 ja magistriastmes õppijad kasutavad enda hinnangul enim õpikuid ja käsiraamatuid. Samas on vahed tekstide kolme sagedasema allika kasutuses väikesed. Ajalehtede vähene kasutamine on akadeemilises õppes ootuspärane. Vähemalt pooled vastanutest, sõltumata emakeelest ja õppeaastast, loevad teadusartikleid ajakirjadest või artiklikogumikest, mis tutvustavad ühte konkreetset uurimust, mõnevõrra vähem loetakse ülevaateartikleid. Kui monograafiate mitte lugemist bakalaureuseastmes võib õigustada teksti liigse raskusega, siis mõistetamatuks jääb üliõpilasuurimuste äärmiselt vähene kasutus, mille põhjuste väljaselgitamine vajab uurimist. Samas on 240 doktorandi küsitlus näidanud, et nendegi hulgas oli ligi viiendik, kes pole lugenud ühtegi doktoritööd (EKÕTEK 2013).

Küsimustiku valiku "muu" alla lisasid küsitletud erialaspetsiifilisi allikaid nagu arhiivitoimikud ja ilukirjandus, kuid märgiti ka, et väga sageli või sageli kasutatakse konspekte ja õppejõudude jagatud esitlusi.

Seega loetakse õppe-eesmärkidel sagedamini kergemini haaratavaid tekste ning jäetakse kõrvale mahukamad teadustööd. Kas selle põhjuseks on ajapuudus, taustteadmiste nappus, mis raskendab niisuguste tekstide lugemist, või suutmatus süveneda ulatuslikku erialadiskursusesse, vajaks edasist uurimist.

Arvutiekraanilt lugemise mahu hindamiseks valisid uurimuses osalejad viie valiku vahel: $0-20 \%, 21-40 \%, 41-60 \%, 61-80 \%, 81-100 \%$, mis vastavad sagedustele väga harva, harva, mõnikord, sageli, väga sageli.

Elektroonse lugemise osakaal on suur kõigi vastanute hulgas (mood 81-100\%), kuigi K2 üliõpilased hindasid selle mahtu pisut väiksemaks (61-80\%). Weiri jt (2012) 2006. aasta uurimuse andmetel oli K1 ja K2 üliõpilasi, kes lugesid tekste arvutis väga sageli, vastavalt $4,1 \%$ ja $8,3 \%$, 
mis näitab, kuidas tehnoloogia areng on kümne aasta jooksul muutnud lugemise viisi. Kuigi leidus paar kommentaari arvutist lugemise kiituseks, lisasid mitmed vastanud, et eelistavad lugeda paberkandjalt:

(1) Eelistan lugeda paberil, kui vaja, prindin teksti välja. (id13)

(2) Loen internetist vaid siis, kui teisiti pole võimalik. (id72)

(3) E-õppe ainetel on palju tekste virtuaalselt. Kui vähegi võimalik, loen paberilt. (id65)

(4) Prindin enamuse materjalist välja, kuna arvutiekraanilt on väga ebamugav lugeda. (id50)

(5) Kahjuks on enamus lugemisest arvuti teel. (id11)

See langeb kokku Diane Mizrachi (2015) uurimuse tulemustega, mille kohaselt üliõpilased küll eelistavad õppetöös paberkandjal materjale elektroonsetele, kuid mitmed põhjused nagu hind, kättesaadavus ja info leidmise kiirus mõjutavad nende tegelikku käitumist.

Eesti keeles lugemise mahtu hinnates valiti samuti viie valiku vahel: $0-20 \%, 21-40 \%, 41-60 \%, 61-80 \%, 81-100 \%$. Ilmnes, et 33,8\% vastanutest loeb eestikeelseid tekste sageli ehk 61-80\% lugemismahust, mis oli ka kõigi vastanute mood. Seejuures loevad mitte-eesti emakeelega (K2) üliõpilased õppeülesannete täimiseks eesti keeles sagedamini kui eesti emakeelega (K1) üliõpilased: 41-80\% juhtudest loeb eesti keeles $80 \%$ K2 üliõpilasi võrrelduna poolte K1 vastanutega.

Ootuspäraselt loevad eestikeelseid tekste kõige sagedamini esmakursuslased ja kõige vähem võõrkeelsetel õppekavadel õppijad ning viienda aasta üliõpilased: kui $81 \%$ esimese aasta üliópilasi hindas eesti keeles lugemist sagedaseks (61-80\%), siis järgnevate aastate üliõpilaste hulgas näitas eesti keeles lugemise osatähtsus langust. See võib olla seletatav kasvava vajadusega lugeda erialast võõrkeelset kirjandust erialakursustel tehtavate tööde ja üliõpilasuurimuste koostamiseks. 


\subsection{Lugemisstrateegiate kasutus}

Lugemisstrateegiate kasutuse sagedust (küsitluse 3. osa) hindasid uurimuses osalejad viieastmelisel skaalal: 5 - alati, 4 - sageli, 3 - mõnikord, 2 - harva, 1 - väga harva. Üliõpilastel paluti lugeda tegevuste kirjeldusi ja mõeldes õppeülesannete täitmisele (nt valmistumine seminariaruteluks või eksamiks; essee, referaadi, üliõpilasuurimuse koostamine), otsustada iga kohta, kui sageli nad seda teevad eesti keeles lugedes.

Vähemalt pooled küsimustiku täitnud üliõpilased kasutavad 24 strateegiast 12 alati või sageli (vt lisa 1). Neist kuue sagedasema kasutus emakeele järgi on esitatud tabelis 4 .

TABEL 4. Sagedasemate strateegiate kasutus emakeele järgi

$(\%$, alati + sageli $)$

\begin{tabular}{|l|c|c|c|}
\hline Strateegia & $\mathbf{N}=\mathbf{8 0}$ & $\begin{array}{c}\text { K1 } \\
\mathbf{N}=\mathbf{4 9}\end{array}$ & $\begin{array}{c}\text { K2 } \\
\mathbf{N}=\mathbf{3 1}\end{array}$ \\
\hline $\begin{array}{c}\text { 1) jätan meelde, kus vajalik info tekstis paikneb } \\
\text { või märgin ära selle asukoha, et oleks lihtsam } \\
\text { ülesannet täita }\end{array}$ & 72,5 & 69,4 & 77,4 \\
\hline $\begin{array}{c}\text { 2) kontrollin mulle tundmatu sõna tähendust } \\
\text { (veebi)sõnaraamatust }\end{array}$ & 68,8 & 61,3 & 80,6 \\
\hline $\begin{array}{c}\text { 3) aiman mulle tundmatu sõna tähendust kon- } \\
\text { teksti ja olemasolevate teadmiste põhjal }\end{array}$ & 68,8 & 77,5 & 54,9 \\
\hline $\begin{array}{c}\text { 4) seostan tekstist saadud infot teadmistega } \\
\text { varem loetud tekstidest }\end{array}$ & 63,7 & 67,4 & 58,1 \\
\hline $\begin{array}{c}\text { 5) joonin alla või teen lugemise käigus märk- } \\
\text { meid ülesande seisukohast olulise info kohta }\end{array}$ & 60,0 & 57,2 & 64,6 \\
\hline $\begin{array}{c}\text { 6) loen teksti detailselt, et üksikasjadest täpselt } \\
\text { aru saada }\end{array}$ & 59,9 & 57,1 & 64,6 \\
\hline
\end{tabular}

Sagedasemate strateegiate hulgas leidub nii mõistmisele (strateegiad 2, $3,6)$, mäletamisele $(1,5)$ kui ka õppimise toetamiseks $(1,4,5)$ suunatud tegevusi.

Loetelu esimene ja viies strateegia on suunatud ülesande täitmisele ja osutavad eesmärgistatud lugemist. Seejuures nende hulgas, kes fikseerivad tekstis vajaliku info alati (1. strateegia), on rohkem K1 üliõpilasi 
$(60,75 \%)$. Seda, et nii eesti kui ka vene emakeelega üliõpilasi iseloomustab eesmärgipärane lugemine, kinnitab ka strateegia loen esiteks kogu teksti läbi, seejärel loen uuesti põhjalikult vähene kasutus mõlema grupi hinnangul: niisugust süvenevat, kuid mittesihipärast lugemistegevust kasutab 35,5\% K2 ja 28,6\% K1 üliõpilastest.

Teine ja kolmas strateegia seostuvad süvalugemisega lokaalsel tasandil ja on eelduseks teksti kui terviku mõistmisele. Kuna tundmatud sõnad tekstis kujutavad endast takistust juba teksti mõistmise madalamal tasandil, on probleemi lahendamine vägagi teadvustatud tegevus, mida kinnitab ka see, et sõna tähenduse kontrollimine sõnaraamatust on mitte-eesti emakeelega üliópilaste sagedasim strateegia. Kui aga sõnaraamatut kasutavad K2 üliõpilased sagedamini kui K1 üliõpilased, siis sõnade tähenduse aimamises konteksti või taustteadmiste põhjal on tulemus vastupidine. Tegemist on uurimuse suurima emakeelest tuleneva erinevusega, mida saab seletada sõnatundmise mõjuga teksti mõistmisele: kui K2 lugejale on tundmatuid sõnu tekstis rohkem kui $2 \%$ (st 1 iga 50 sõna kohta), mis on erialateksti silmas pidades ootuspärane, on teksti adekvaatne mõistmine raskendatud (Nation 2006: 61). See omakorda tähendab, et ka sõna tähenduse tuletamine konteksti põhjal ei pruugi õnnestuda.

Seda, et üliõpilased tundmatute sõnadega tegelevad, kinnitab ka strateegia jätan mulle tundmatud sõnad tähelepanuta ja jätkan lugemist paiknemine sageduselt viimasel kohal (vt lisa 1). Ka Weiri jt (2012: 72) tulemused näitasid, et $2 / 3$ vastanutest selgitavad tundmatu sõna tähenduse välja, kuid kuna nende küsimustikus puudusid valikud otsese (sõnaraamatu kasutamine) ja kaudse (järeldamine) tegevuse kohta, pole neid andmeid võimalik võrrelda.

Taustteadmiste kasutamine tähenduse tuletamiseks ja uute teadmiste seostamine olemasolevatega (3. ja 4. strateegia) näitab, et umbes $2 / 3$ vastanute lugemistegevusse on kaasatud teksti mõistmise kõrgema tasandi komponendid. Kui kolmanda strateegia kasutuses võib täheldada emakeelest tulenevaid erinevusi, siis neljanda kasutuses märkimisväärset erinevust ei ole. 
Kuue sagedasema strateegia võrdlus Weiri jt (2012: 72) tulemustega näitab kokkulangevust esimese ja viienda kasutussageduses. Viimase puhul sarnanevad eesti ja Briti K2 üliõpilaste tulemused (vastavalt 64,6\% ja 66,4\%), kuid tulemused erinevad K1 grupis (vastavalt $57,2 \%$ ja $78,7 \%$ ). Võimalik, et lugemise käigus märkmete tegemine ei ole eesti üliõpilaste hulgas nii levinud, kui see oli 10 aastat tagasi Briti üliõpilaste seas. Kuidas täpsemalt üliõpilased ülesande seisukohast olulist teavet leiavad, meelde jätavad ja kasutavad, võiks olla edasise uurimise küsimus.

Bakalaureuse- ja magistriüliõpilaste strateegiakasutuses kokku suuri erinevusi ei esine, küll aga võib märgata muutusi mõnede strateegiate kasutuses õppeaastate lõikes (vt tabel 5).

TABEL 5. Sagedasemate strateegiate kasutus óppeaastati (\%, alati + sageli)

\begin{tabular}{|c|c|c|c|c|c|}
\hline Strateegia & $\begin{array}{c}1 . \mathrm{a} \\
\mathrm{N}=11\end{array}$ & $\begin{array}{c}2 . \mathrm{a} \\
\mathrm{N}=14\end{array}$ & $\begin{array}{c}\text { 3. } a \\
N=18\end{array}$ & $\begin{array}{c}4 . \mathrm{a} \\
\mathrm{N}=31\end{array}$ & $\begin{array}{c}5 . \mathrm{a} \\
\mathrm{N}=6\end{array}$ \\
\hline $\begin{array}{l}\text { 1) jätan meelde, kus vajalik } \\
\text { info tekstis paikneb või } \\
\text { märgin ära selle asukoha, } \\
\text { et oleks lihtsam ülesannet } \\
\text { täita }\end{array}$ & 91,0 & 85,8 & 66,7 & 67,7 & 50,0 \\
\hline $\begin{array}{l}\text { 2) kontrollin mulle tundmatu } \\
\text { sõna tähendust (veebi) } \\
\text { sõnaraamatust }\end{array}$ & 72,8 & 78,6 & 66,6 & 61,3 & 88,3 \\
\hline $\begin{array}{l}\text { 3) aiman mulle tundmatu } \\
\text { sõna tähendust konteksti } \\
\text { ja olemasolevate teadmiste } \\
\text { põhjal }\end{array}$ & 72,8 & 71,4 & 55,5 & 71,0 & 83,0 \\
\hline $\begin{array}{l}\text { 4) seostan tekstist saadud } \\
\text { infot teadmistega varem } \\
\text { loetud tekstidest }\end{array}$ & 72,8 & 57,1 & 83,3 & 51,6 & 66,6 \\
\hline $\begin{array}{l}\text { 5) joonin alla või teen luge- } \\
\text { mise käigus märkmeid } \\
\text { ülesande seisukohast } \\
\text { olulise info kohta }\end{array}$ & 54,5 & 57,1 & 50,0 & 67,8 & 66,6 \\
\hline $\begin{array}{l}\text { 6) loen teksti detailselt, et } \\
\text { üksikasjadest täpselt aru } \\
\text { saada }\end{array}$ & 72,7 & 57,1 & 66,6 & 48,4 & 83,4 \\
\hline
\end{tabular}


Näiteks on ülesande seisukohast olulise info tuvastamine olulisem esimese ja teise aasta üliõpilastele, kuid märkmeid selle kohta teevad pigem magistrandid. Sõnade tähendusega tegelemine on tähtis kõigil õppeaastatel. Samas võib märgata, et tähenduse väljaselgitamine on pisut vähem oluline kolmanda aasta üliõpilastele, muutudes taas tähtsamaks magistriõppes. Valimi väiksus ei võimalda selle tulemuse kohta üldistavaid järeldusi teha. Kas see on juhuslik varieeruvus või mingi tendents, vajaks edasist uurimist.

Muude, vähem sagedaste strateegiate kasutamise statistika põhjal (vt lisa 1) võib öelda, et K2 üliõpilastel on emakeelekõnelejatega võrreldes strateegiate kasutus üldiselt sama või sagedasem. Lisaks sõnaraamatukasutusele on K2 üliõpilastele olulisem teksti struktuuri ja visuaalse toe kasutamine teksti kasulikkuse hindamisel (vaatan pealkirju, vahepealkirju ja poolpaksus kirjas esile tõstetud sõnu-lauseid, enne kui otsustan teksti põhjalikult lugeda). Seda teeb 54,8\% K2 küsitletuid võrrelduna 40,8\% emakeelekõnelejatega. Weiri jt (2012) tulemused näitasid sama tendentsi, kuid erinevalt siinsetest üliõpilastest kasutavad Briti üliõpilased seda strateegiat palju sagedamini: $82,1 \%$ (K2) ja 73,3\% (K1). Veel selgub, et nimetatud strateegia olulisus õpingute edenedes kasvab: kui 1. aasta õppijatest kasutab seda $27,3 \%$, siis järgnevate aastate näitajad on $42,9 \%$ (2. a), $44,5 \%$ (3. a), 51,6\% (4. a), 66,6\% (5. a).

Mitte-eesti emakeelega üliópilastele on olulisem teinegi lugemistegevuse kavandamise strateegia (mõtlen enne lugema hakkamist põhjalikult ja otsustan, mida ma tekstist täpselt otsin): alati või sageli planeerivad oma lugemistegevust põhjalikult $61,3 \% \mathrm{~K} 2$ ja 51\% K1 üliõpilastest. Erinevalt eelmisest strateegiast näitab selle kasutus õppeaastati langustrendi: seda kasutab üle $80 \%$ 1.-2. aasta üliõpilastest, kuid järgnevate aastate üliõpilaste seas langeb selle tähtsus alla 50\%. Võib oletada, et lugemisvilumuse ja erialateadmiste suurenedes strateegia olulisus väheneb, sest lugemistegevuse kavandamine on kujunenud automaatseks, teadvustamata oskuseks.

Kogu tekstile rakendatavaid süvalugemise strateegiaid loen teksti detailselt, et üksikasjadest täpselt aru saada ja teen mõttes loetust kokkuvõtteid kasutavad taas sagedamini pigem 1. aasta ja K2 üliõpilased. See 
on mõistetav, kuna süvenevast ja seoseid loovast lugemistegevusest on teadlikumad need, kellele erialase teksti mõistmine võib suurema tõenäosusega põhjustada raskusi: äsja mingit eriala õppima asunud ja õppekeelest erineva emakeelega üliõpilased. Introspektiivsed uurimused on näidanud tugevat seost kokkuvõtete tegemise ja järeldamisoskuse vahel: lugejad, kes sageli teevad loetust kokkuvõtteid, on demonstreerinud ka head järeldamisoskust (Cromley \& Wills 2016: 53). Teksti lineaarse süvalugemise sagedus (jõuan teksti mõistmiseni samm-sammult, lugedes lauseid süvenemisega teksti kulgemise järjekorras) jääb aastate lõikes vahemikku 51-66,6\% ning seda esineb rohkem mitte-eesti üliõpilaste lugemises (63\% vs. $57 \%)$.

Lugemistegevuseks, mida aga K1 üliõpilased lisaks sõnade tähenduse aimamisele sagedamini kasutavad, on korduv lugemine (loen tekstiosi mitu korda üle, et mõttest aru saada). Seda teeb alati või sageli 57,2\% eesti emakeelega üliõpilastest võrrelduna K2 üliõpilaste 38,7\%.

\section{3. Õppeülesannete täitmisel kogetud lugemisraskused}

Lugemisraskuste (vt lisa 2) hindamiseks paluti üliõpilastel otsustada iga raskuse kohta, kui sageli neil seda esineb eesti keeles lugedes. Sagedust hinnati viiepallisel skaalal: 5 - alati, 4 - sageli, 3 - mõnikord, 2 - harva, 1 - väga harva. Tabelis 6 on valikud esitatud küsitluse sõnastuses.

TABEL 6. Sagedasemad lugemisraskused emakeele ja óppeastme järgi $(\%$, alati + sageli $)$

\begin{tabular}{|l|c|c|c|c|c|}
\hline Raskused & $\mathbf{N}=\mathbf{8 0}$ & $\begin{array}{c}\text { K1 } \\
\mathbf{N}=\mathbf{4 9}\end{array}$ & $\begin{array}{c}\text { K2 } \\
\mathbf{N}=\mathbf{3 1}\end{array}$ & $\begin{array}{c}\text { 1.-3. } \mathbf{a} \\
\mathbf{N}=\mathbf{4 3}\end{array}$ & $\begin{array}{c}\text { 4.-5. } \mathbf{~} \\
\mathbf{N}=\mathbf{3 7}\end{array}$ \\
\hline $\begin{array}{c}\text { 1) tekstidega, mille teema on } \\
\text { keerukas }\end{array}$ & 48,8 & 46,9 & 51,6 & 55,3 & 45,9 \\
\hline $\begin{array}{c}\text { 2) teksti mõistmisega, kui } \\
\text { mul puuduvad vajalikud } \\
\text { teadmised teema kohta }\end{array}$ & 48,8 & 44,9 & 54,9 & 47,8 & 42,1 \\
\hline $\begin{array}{c}\text { 3) tundmatute sõnadega } \\
\text { tekstis }\end{array}$ & 36,2 & 29,6 & 48,4 & 43,5 & 24,5 \\
\hline
\end{tabular}


LUGEMISSTRATEEgIATE KASUTUS AKADEEMILISES ÕPPES

\begin{tabular}{|l|c|c|c|c|c|}
\hline Raskused & $\mathbf{N}=\mathbf{8 0}$ & $\begin{array}{c}\text { K1 } \\
\mathbf{N}=\mathbf{4 9}\end{array}$ & $\begin{array}{c}\text { K2 } \\
\mathbf{N}=\mathbf{3 1}\end{array}$ & $\begin{array}{c}\mathbf{1 . - 3 .} \mathbf{\mathbf { a }} \\
\mathbf{N}=\mathbf{4 3}\end{array}$ & $\begin{array}{c}\text { 4.-5. a } \\
\mathbf{N}=\mathbf{3 7}\end{array}$ \\
\hline $\begin{array}{c}\text { 4) tekstidega, mis käsitlevad } \\
\text { erinevaid teooriaid }\end{array}$ & 28,8 & 26,5 & 32,3 & 40,9 & 24,7 \\
\hline $\begin{array}{c}\text { 5) teksti kiire lugemisega, et } \\
\text { otsustada, kas ja missugu- } \\
\text { seid osi peaksin ülesande } \\
\text { täitmiseks detailselt lugema }\end{array}$ & 28,8 & 22,4 & 38,8 & 32,8 & 19,7 \\
\hline $\begin{array}{c}\text { 6) pikkade tekstide lugemi- } \\
\text { sega }\end{array}$ & 28,7 & 30,6 & 25,8 & 30,9 & 27,9 \\
\hline
\end{tabular}

Andmetest selgub, et taustteadmised mõjutavad erialatekstist arusaamist olulisel määral, põhjustades raskusi umbes pooltel uurimuses osalenud üliõpilastel. Seejuures ei ole keerukat teemat käsitlevate tekstide mõistmisel (raskused 1 ja 4) ka emakeelekõnelejad eelisolukorras, mis sarnaneb ka Weiri jt (2012) samade tulemustega.

Ootuspäraselt põhjustavad rasked sõnad tekstis rohkem probleeme K2 üliõpilastele, mis langeb kokku vastavate strateegiate kasutuse sagedusega (vt tabel 4), kinnitades, et takistused madalama tasandi keeletöötluses mõjutavad teksti mõistmist tervikuna. Teksti lauseehitusest tulenevaid raskusi (vt lisa 2), mis on samuti seotud lingvistilise teabe töötlemisega, tajuvad pisut enam K2 üliõpilased kui K1 üliõpilased (vastavalt $22,2 \%$ ja $12, \%)$. Siin võib täheldada sarnasusi inglise keeles lugemise kohta saadud varasemate uurimistulemustega, mille põhjal Cobb ja Horst (2001) on järeldanud, et sõnatundmine on lingvistilistest teadmistest keskne teksti eduka mõistmise komponent akadeemilises õppes ja seda nii K1 kui ka K2 lugejatele. Seejuures mõjutab sõnatundmine teises keeles lugemist rohkem kui muud keeleteadmised, sh süntaksiteadmised. (Cobb \& Horst 2001: 318)

Viies raskus seostub kogu tekstile rakendatava, kiire ja tõhusa lugemise tegevusega, mis on orienteeritud ülesande täitmisele. Kuigi seda raskust tajub keskmiselt vaid napilt kolmandik vastanutest, võib siin märgata K2 üliõpilaste ülekaalu. See langeb kokku tähelepanekutega, mille kohaselt just silmava lugemise tegevused eristavad K1 ja K2 lugejaid (Weir jt 2000; Bax 2013). 
Lugejate lähenemine tekstile sama ülesannet täites võib olla väga erinev (vt Kikerpill 2012; Kikerpill \& Türk 2013), kuid võib sellele vaatamata anda soovitud tulemusi. Kui aga ülesande täitmisega kaasneb ajaline surve nagu sageduselt viienda raskusega seotud lugemistegevuses (vt tabel 6), võib teksti mõistmist mõjutada ka see, kas loetakse paberilt või arvutiekraanilt. On leitud, et paberilt lugemine annab eksamil paremaid tulemusi juhul, kui sooritusaeg on piiratud. Kui aga ajasurve puudub või on võimalik kasutada eelistatud sooritusviisi, ei ole tulemustes erinevusi (Ackerman \& Lauterman 2012; 2014; vt ka Mangen jt 2013).

Sagedasemate lugemisraskuste võrdlus õppeastmeti kinnitab, et taustteadmiste osatähtsus teksti mõistmisel ei kahane ka magistriõppes. Samas on magistriüliõpilased võrreldes bakalaureuseüliõpilastega suutlikumad kiiresti otsustama tekstide olulisuse üle ning tajuvad vähem raskusi teoreetiliste käsitluste mõistmisel. Selle põhjuseks võib pidada kasvanud lugemisvilumust ning erialateadmiste, sh -terminoloogia paremat valdamist.

Võrdlusest Weiri jt (2012) uurimusega selgub, et kuue sagedasema raskuse hulgas on samu raskusi koguni neli (vt tabel 6, raskused 1, 2, $3,6)$ ning sama on ka enim raskusi põhjustav olukord: teksti keerukas teema on probleemiks 70,2\% K1 ja 58,5\% K2 Briti üliõpilastele.

\section{Kokkuvõtteks}

Artiklis oli vaatluse all üliõpilaste teadvustatud lugemiskäitumine akadeemilises õppes.

Üldise konteksti kohta, milles üliõpilased täidavad lugemist nõudvaid ülesandeid, selgus uurimusest, et enamasti loetakse tekste elektroonilisel kujul, kuigi paljud eelistavad lugeda paberilt. Eesti keeles lugemise maht on suurem esimese aasta ja mitte-eesti emakeelega üliõpilaste hulgas. Õppeülesannete täitmiseks kasutatavate tekstide peamisteks allikateks on pigem kergemini haaratavad tekstid nagu õpikud ja käsiraamatud ning internetiallikad ning vähem teaduskirjandus. Kuigi kaitstud üliõpilastööd on internetis kättesaadavad, loevad üliõpilased neid väga harva. 
Strateegiakasutuse analüüs näitas, et nii eesti kui ka mitte-eesti emakeelega üliõpilased on eesmärgipärased lugejad, kavandades lugemist ülesandest lähtuvalt ja kasutades meeldejätmist toetavaid tegevusi. K2 üliõpilasi võrreldes $\mathrm{K} 1$ vastanutega iseloomustab rohkemate strateegiate sagedasem kasutus, detailsem lugemine ja sagedamini tajutavad lugemisraskused, mis kokku annab tunnistust suuremast pingutusest tekstide mõistmisel. Tundmatute sõnade tähenduse väljaselgitamine on nii K1 kui ka K2 üliõpilaste kõige sagedasem strateegia, kuid kui mitteeesti emakeelega üliõpilased kasutavad selleks peamiselt sõnaraamatut, siis eesti emakeelega üliõpilased püüavad sagedamini aimata sõna tähendust konteksti või taustteadmiste abil.

Peamised tajutavad lugemisraskused on seotud taustteadmistega (teksti mõistmise kõrgem tasand) ja sõnatundmisega. Taustteadmistest põhjustatud raskused püsivad samal tasemel nii emakeele kui ka õppeaastate lõikes, näidates erinevate teadmiste olulisust erialatekstide mõistmisel. Sõnatundmisega seotud raskused kinnitavad strateegiakasutuse tulemusi: sagedasemad takistused sõnatuvastuses tingivad sagedasemat sõnaraamatu kasutamist ning mõjutavad teksti mõistmise kõrgema tasandi tegevusi.

Võrdlus Briti üliõpilaste seas läbi viidud uurimusega (Weir jt 2012) osutab vaatamata erinevusele valimi suuruses sarnastele tendentsidele nii lugemisstrateegiate kasutuses kui ka teksti mõistmisel tajutavates raskustes. Erinevustena võib märkida keeleteadmiste suuremat osatähtsust TÜ üliõpilaste jaoks.

Tulemused kinnitavad, et akadeemiliste tekstide lugemisel on raskusi nii emakeeles kui ka teises keeles õppijatel. Seetõttu võiks soovitada spetsiaalsete, akadeemilist keelekasutust arendavate eesti keele kursuste kõrval pöörata tekstide mõistmisele rohkem tähelepanu just erialakursustel. Keelekursused aitavad kujundada üldakadeemilisi oskusi nagu akadeemilise teksti ülesehituse ja keelekasutuse põhimõtete rakendamine, kuid erialakursustel on võimalik välja selgitada erialadiskursusega (sh taustteadmiste ja terminoloogiaga) seotud mõistmisraskusi ja toetada tervikliku ainekäsituse kujunemist kogu stuudiumi vältel. 


\section{Kirjandus}

Ackerman, Rakefet, Tirza Lauterman 2012. Taking reading comprehension exams on screen or on paper? A metacognitive analysis of learning texts under time pressure. - Computers in Human Behavior 28 (5), 1816-1828. https:// doi.org/10.1016/j.chb.2012.04.023

Ackerman, Rakefet, Tirza Lauterman 2014. Overcoming screen inferiority in learning and calibration. - Computers in Human Behavior 35, 455-463. https://doi.org/10.1016/j.chb.2014.02.046

Alderson, Charles 2000. Assessing Reading. Cambridge: Cambridge University Press. https://doi.org/10.1017/CBO9780511732935

Alderson, Charles 1984. Reading in a foreign language: A reading problem or a language problem? - J. C. Alderson, A. H. Urquhart (Eds.), Reading in a Foreign Language. London: Longman, 1-24.

Bax, Steven 2013. Students' cognitive processes during IELTS reading test: Evidence from eye-tracking. ELT Research Papers 13-06. London: British Council.

Bernhardt, Elizabeth, Michael Kamil 1995. Interpreting relationships between L1 and $\mathrm{L} 2$ reading: Consolidating the linguistic threshold and the linguistic interdependence hypotheses. - Applied Linguistics 16 (1), 15-34. https:// doi.org/10.1093/applin/16.1.15

Bialystok, Ellen, Gigi Luk, Ernest Kwan 2005. Bilingualism, biliteracy, and learning to read: Interactions among languages and writing systems. - Scientific Studies of Reading 9 (1), 43-61. https://doi.org/10.1207/s1532799xssr0901_4

Bråten, Ivar, Helge Strømsø 2003. A longitudinal think-aloud study of spontaneous strategic processing during the reading of multiple expository texts. Reading and Writing: An Interdisciplinary Journal 16 (3), 195-218. https:// doi.org/10.1023/A:1022895207490

Cobb, Tom, Marlise Horst 2001. Reading academic English: Carrying learners across the lexical threshold. - J. Flowerdew, M. Peacock (Eds.), Research Perspectives on English for Academic Purposes. Cambridge: Cambridge University Press, 315-329.

Cohen, Andrew 2006. The coming age of research on test-taking strategies. Language Assessment Quartery 3 (4), 307-331. https://doi.org/10.1080 /15434300701333129

Cromley, Jennifer, Theodore Wills 2016. Flexible strategy use by students who learn much versus little from text: Transition within think-aloud protocol. - Journal of Research in Reading 39 (1), 50-71. https://doi. org/10.1111/1467-9817.12026 
Ehala, Martin, Krista Kerge, Kersti Lepajõe, Kadri Sõrmus 2010. Kõrgkoolide üliõpilaste eesti keele oskuse tase. Uuringukokkuvõte. Tartu Ülikool.

Ehala, Martin, Krista Kerge, Kersti Lepajõe, Kadri Sõrmus 2015. Kõrgkoolide üliõpilaste eesti keele oskuse tase. Kordusuuring. Uuringu kokkuvõte. Tartu Ülikool.

EKÕTEK = Eesti keel kõrghariduse ja teaduse keelena. Uuringu sisuaruanne. Tallinna Ülikool, 2013. http://dspace.ut.ee/handle/10062/40694

Grabe, William 2009. Reading in a Second Language. Moving from Theory to Practice. Cambridge Applied Linguistics. Cambridge University Press.

Han, Feifei 2015. Word recognition research in foreign language reading. - University of Sydney Papers in TESOL 10, 57-91.

Hellekjær, Glenn Ole 2009. Academic English reading proficiency at the university level: A Norwegian case study. - Reading in a Foreign Language 21 (2), $198-222$.

Hermida, Julian 2009. The importance of teaching academic reading skills in first-year university courses. - The International Journal of Research and Review 3, 20-30. https://doi.org/10.2139/ssrn.1419247

Hirsjärvi, Sirkka, Pirkko Remes, Paula Sajavaara 2005. Uuri ja kirjuta. Tallinn: Kirjastus Medicina.

Jeon, Eun Hee, Junko Yamashita 2014. L2 reading comprehension and its correlates: A metaanalysis. - Language Learning 64 (1), 160-212. https://doi. org/10.1111/lang.12034

Jordan, Robert R. 1997. English for Academic Purposes: A Guide and Resource Book for Teachers. Cambridge: Cambridge University Press. https://doi. org/10.1017/CBO9780511733062

Khalifa, Hanan, Cyril Weir 2009. Examining Reading. Research and practice in assessing second language reading. Studies in Language Testing 29. Cambridge: Cambridge University Press.

Kikerpill, Tiina 2012. Enesevaatlus lugemistesti valiidsuse uurimisel ['Self-observation in validating reading test']. - Eesti ja soome-ugri keeleteaduse ajakiri / Journal of Estonian and Finno-Ugric Linguistics 3 (2), 79-112.

Kikerpill, Tiina, Ülle Türk 2013. Tekstisisesed seosed eesti keele kui teise keele lugemistestis: mõõtmisvahendi valiidsus ['Testing understanding text cohesion and coherence in Estonian as a second language: the validity of different task types']. - Lähivõrdlusi. Lähivertailuja 23, 122-147. https:// doi.org/10.5128/LV23.05

Kintsch, Walter 1988. The role of knowledge in discourse processing: A construction-integration model. - Psychological Review 95, 163-182. https://doi. org/10.1037/0033-295X.95.2.163 
Krishnan, Sarojani Devi 2010. Validating Aspects of a Model of Academic Reading. University of Bedfordshire. http://ethos.bl.uk/OrderDetails. do?did=1\&uin=uk.bl.ethos.575513 (27.7.2017).

Kong, Ailing 2006. Connections between L1 and L2 readings: Reading strategies used by four Chinese adult readers. - The Reading Matrix 6 (2), 19-45.

Koda, Keiko 2004. Insights into Second Language Reading. A Cross-linguistic Approach. Cambridge: Cambridge University Press.

Mangen, Anne, Bente Walgermo, Kolbjørn Brønnick 2013. Reading linear texts on paper versus computer screen: Effects on reading comprehension. International Journal of Educational Research 58, 61-68. https://doi. org/10.1016/j.ijer.2012.12.002

McNamara, Danielle, Joe Magliano 2009. Toward a comprehensive model of comprehension. - Brian Ross (Ser. Ed.), The Psychology of Learning and Motivation 51. Burlington: Academic Press, 297-384.

Metslang, Helena, Anastassia Šmõreitšik 2012. Muukeelse tudengi keeleline toimetulek ja vajadused ülikoolis. Tallinna Ülikool. http://hdl.handle. net/10062/40754

Mizrachi, Diane 2015. Undergraduates' academic reading format preferences and behaviors. - The Journal of Academic Librarianship 41 (3), 301-311. https://doi.org/10.1016/j.acalib.2015.03.009

Nassaji, Hossein 2014. The role and importance of lower-level processes in second language reading. - Language Teaching 47 (1), 1-37. https://doi. org/10.1017/S0261444813000396

Nation, Paul 2006. How large vocabulary is needed for reading and listening? The Canadian Modern Language Review 63 (1), 59-82. https://doi. org/10.3138/cmlr.63.1.59

Phakiti, Aek 2003. A closer look at the relationship of cognitive and metacognitive strategy use to EFL reading achievement test performance. - Language Testing 20 (1), 26-56. https://doi.org/10.1191/02655322031t243oa

Puksand, Helin 2010. Tekstid, mida loevad teismelised. Teismeliste lugemisharjumuste kasutamine koolis. - Krista Kerge (Toim.), Tekstiuurimus ja kool. Tallinn: Tallinna Ülikooli Kirjastus, 20-35.

Rapp, David, Paul van den Broek, Kristen McMaster, Panayiota Kendeou, Christine Espin 2007. Higher-order comprehension processes in struggling readers: A perspective for research and intervention. - Scientific Studies of Reading 11 (4), 289-312. https://doi.org/10.1080/10888430701530417

Sheorey, Ravi, Kouider Mokhtari 2001. Differences in the metacognitive awareness of reading strategies among native and non-native readers. - System 29, 431-449. https://doi.org/10.1016/S0346-251X(01)00039-2 
Soodla, Piret, Eve Kikas 2014. Lugemisoskuse ja -motivatsiooni seosed õpetajate kasvatusstiilidega esimeses klassis ['Relations of reading skills and motivation with teaching styles in first grade']. - Eesti Haridusteaduste Ajakiri 2 (1), 67-95. https://doi.org/10.12697/eha.2014.2.1.04

Taboada, Ana, John Guthrie 2006. Contribution of student questioning and prior knowledge to construction of knowledge from reading information text. - Journal of Literacy Research 38 (1), 1-35. https://doi.org/10.1207/ s15548430jlr3801_1

Taraban, Roman, Marcel Kerr, Kimberly Rynearson 2004. Analytic and pragmatic factors in college students' metacognitive reading strategies. - Reading Psychology 25 (2), 67-81. https://doi.org/10.1080/02702710490435547

Urquhart, Alexander, Cyril Weir 1998. Reading in a Second Language: Process, Product and Practice. New York: Longman.

Uibu, Krista, Mairi Männamaa 2014. Õpetamistegevused ja õpilaste tekstimõistmine üleminekul esimesest kooliastmest teise astmesse ['Teaching practices and text comprehension in students during the transition from the first to second stage of school']. - Eesti Haridusteaduste Ajakiri 2 (1), 96-131. https://doi.org/10.12697/eha.2014.2.1.05

van Gelderen, Amos, Rob Schoonen, Kees de Glopper, Jan Hulstijn, Annegien Simis, Patrick Snellings, Marie Stevenson 2004. Linguistic knowledge, processing speed, and metacognitive knowledge in first- and second-language reading comprehension: A componential analysis. - Journal of Educational Psychology 96 (1), 19-30. https://doi.org/10.1037/0022-0663.96.1.19

Weir, Cyril, Roger Hawkey, Anthony Green, Aylin Ünaldi, Sarojani Devi 2012. The relationship between the academic reading construct as measured by IELTS and the reading experiences of students in their first year of study at a British University. - Lynda Taylor, Cyril J Weir (Eds.), IELTS Collected Papers 2. Research in reading and listening assessment. Cambridge: Cambridge University Press, 37-119.

Weir, Cyril, Yang Huizhong, Jin Yan (Eds.) 2000. An Empirical Investigation of the Componentiality of L2 Reading in English for Academic Purposes. Studies in Language Testing 12. Cambridge: Cambridge University Press.

Walter, Catherine 2007. First- to second language reading comprehension: not transfer, but access. - International Journal of Applied Linguistics 17 (1), 14-37. https://doi.org/10.1111/j.1473-4192.2007.00131.x 
Lisa 1. Lugemisstrateegiate kasutuse sagedused (alati ja sageli, \% vastanutest, $\mathbf{N}=80$ )

\begin{tabular}{|c|c|c|c|}
\hline $\begin{array}{l}\text { Kui loen tekste mingi õppeülesande } \\
\text { täitmise eesmärgil, }\end{array}$ & Alati & Sageli & $\mathrm{A}+\mathrm{S}$ \\
\hline $\begin{array}{l}\text { 1) jätan meelde, kus vajalik info tekstis } \\
\text { paikneb või märgin ära selle asukoha, et } \\
\text { oleks lihtsam ülesannet täita. }\end{array}$ & $35,0(1)$. & 37,5 & 72,5 (1.) \\
\hline $\begin{array}{l}\text { 2) kontrollin mulle tundmatu sõna } \\
\text { tähendust (veebi)sõnaraamatust. }\end{array}$ & $22,5(2)$. & 46,3 (3.) & $68,8(2)$. \\
\hline $\begin{array}{l}\text { 3) aiman mulle tundmatu sõna tähendust } \\
\text { konteksti ja olemasolevate teadmiste } \\
\text { põhjal. }\end{array}$ & 11,3 & 57,5 (1.) & $68,8(2)$. \\
\hline $\begin{array}{l}\text { 4) seostan tekstist saadud infot } \\
\text { teadmistega varem loetud tekstidest. }\end{array}$ & $22,5(2)$. & 41,2 & 63,7 (3.) \\
\hline $\begin{array}{l}\text { 5) joonin alla või teen lugemise käigus } \\
\text { märkmeid ülesande seisukohast olulise } \\
\text { info kohta. }\end{array}$ & $22,5(2)$. & 37,5 & $60,0(4)$. \\
\hline $\begin{array}{l}\text { 6) loen teksti detailselt, et üksikasjadest } \\
\text { täpselt aru saada. }\end{array}$ & 8,7 & $51,2(2)$. & 59,9 (5.) \\
\hline $\begin{array}{l}\text { 7) jõuan teksti mõistmiseni samm- } \\
\text { sammult, lugedes lauseid süvenemisega } \\
\text { teksti kulgemise järjekorras. }\end{array}$ & 15,0 & 43,8 & $58,8(6)$. \\
\hline $\begin{array}{l}\text { proovin seostada teksti sisu oma } \\
\text { eelnevate teadmistega ja hinnata teksti } \\
\text { olulisust. }\end{array}$ & 18,8 & 40,0 & $58,8(6)$. \\
\hline $\begin{array}{l}\text { 9) mõtlen enne lugema hakkamist } \\
\text { põhjalikult ja otsustan, mida ma tekstist } \\
\text { täpselt otsin. }\end{array}$ & 17,5 & 37,5 & $55,0(7)$. \\
\hline $\begin{array}{l}\text { 10) tutvun põhjalikult ülesandega ja } \\
\text { proovin võtmesõnade abil leida tekstist } \\
\text { ülesande täitmiseks vajalikud kohad. }\end{array}$ & 20,0 (3.) & 35,0 & 55,0 (7.) \\
\hline 11) teen mõttes loetust kokkuvõtteid. & 20,0 (3.) & 35,0 & $55,0(7)$. \\
\hline $\begin{array}{l}\text { 12) loen tekstiosi mitu korda üle, et mõttest } \\
\text { aru saada. }\end{array}$ & 7,5 & 42,5 & 50,0 (8.) \\
\hline $\begin{array}{l}\text { 13) vaatan kiiresti kogu teksti läbi, enne kui } \\
\text { hakkan üldse midagi tegema. }\end{array}$ & 20,0 (3.) & 27,5 & 47,5 (9.) \\
\hline
\end{tabular}




\begin{tabular}{|c|c|c|c|}
\hline $\begin{array}{l}\text { Kui loen tekste mingi õppeülesande } \\
\text { täitmise eesmärgil, }\end{array}$ & Alati & Sageli & $A+S$ \\
\hline $\begin{array}{l}\text { 14) proovin aru saada, missugune on teksti } \\
\text { struktuur: kuidas mõtted ja üksikasjad } \\
\text { on omavahel seotud. }\end{array}$ & 12,5 & 33,8 & 46,3 (10.) \\
\hline $\begin{array}{l}\text { 15) vaatan pealkirju, vahepealkirju ja } \\
\text { poolpaksus kirjas esile tõstetud } \\
\text { sõnu-lauseid, enne kui otsustan teksti } \\
\text { põhjalikult lugeda. }\end{array}$ & 17,5 & 28,7 & 46,2 (11.) \\
\hline $\begin{array}{l}\text { 16) mõtlen võtmesõnadele ja püüan } \\
\text { võtmesõnu või nende sünonüüme } \\
\text { tekstist kiiresti leida, et otsustada, kas } \\
\text { on mõtet tekstisse süveneda. }\end{array}$ & 15,0 & 26,3 & 41,3 (12.) \\
\hline $\begin{array}{l}\text { 17) teen lugemise käigus tihti pause, et } \\
\text { loetu üle mõtiskleda. }\end{array}$ & 10,0 & 31,3 & 41,3 (13.) \\
\hline $\begin{array}{l}\text { 18) vaatan üle juba loetud tekstiosi, et } \\
\text { kontrollida tähendusest arusaamist. }\end{array}$ & 6,3 & 35,0 & 41,3 (13.) \\
\hline $\begin{array}{l}\text { 19) loen kriitiliselt (analüüsin), et välja } \\
\text { selgitada autori seisukohta mingis } \\
\text { konkreetses küsimuses. }\end{array}$ & 10,0 & 30,0 & 40,0 (14.) \\
\hline $\begin{array}{l}\text { 20) loen esiteks kogu teksti läbi, seejärel } \\
\text { loen uuesti põhjalikult. }\end{array}$ & 10,0 & 21,2 & 31,2 (15.) \\
\hline $\begin{array}{l}\text { 21) loon esmalt tekstist üldisema } \\
\text { ettekujutuse, lugedes näiteks esimest } \\
\text { lõiku ja kokkuvõtet ning teiste lõikude } \\
\text { algusi. }\end{array}$ & 6,3 & 22,5 & 28,8 (16.) \\
\hline $\begin{array}{l}\text { 22) loen tekstist ainult neid kohti, mis } \\
\text { seostuvad ülesandega. }\end{array}$ & 3,7 & 23,7 & 27,4 (17.) \\
\hline $\begin{array}{l}\text { 23) loen kogu teksti põhjalikult algusest } \\
\text { lõpuni läbi, isegi kui mõned kohad ei } \\
\text { seostu minu ülesandega. }\end{array}$ & 3,7 & 22,5 & 26,2 (18.) \\
\hline $\begin{array}{l}\text { 24) jätan mulle tundmatud sõnad } \\
\text { tähelepanuta ja jätkan lugemist. }\end{array}$ & 1,3 & 6,3 & 8,0 (19.) \\
\hline
\end{tabular}




\section{Lisa 2. Lugemisraskuste sagedused} (alati ja sageli, \% vastanutest, $\mathbf{N}=80$ )

\begin{tabular}{|c|c|c|c|c|}
\hline & $\begin{array}{l}\text { i loen tekste mingi õppeülesande täit- } \\
\text { se eesmärgil, on mul raskusi }\end{array}$ & Alati & Sageli & $A+S$ \\
\hline 1) & tekstidega, mille teema on keerukas. & 2,5 & 46,3 (1.) & 48,8 (1.) \\
\hline & $\begin{array}{l}\text { teksti mõistmisega, kui mul puuduvad } \\
\text { vajalikud teadmised teema kohta. }\end{array}$ & $13,8(1)$. & $35,0(2)$. & 48,8 (1.) \\
\hline 3) & tundmatute sõnadega tekstis. & $7,5(3)$. & $28,7(3)$. & 36,2 (2.) \\
\hline & $\begin{array}{l}\text { tekstidega, mis käsitlevad erinevaid } \\
\text { teooriaid. }\end{array}$ & 2,5 & 26,3 & $28,8(3)$. \\
\hline & $\begin{array}{l}\text { teksti kiire lugemisega, et otsustada, } \\
\text { kas ja missuguseid osi peaksin ülesande } \\
\text { täitmiseks detailselt lugema. }\end{array}$ & 2,5 & 26,3 & 28,8 (3.) \\
\hline 6) & pikkade tekstide lugemisega. & $8,7(2)$. & 20,0 & 28,7 \\
\hline 7) & teksti lauseehitusega. & 3,7 & 15,0 & 18,7 \\
\hline 8) & $\begin{array}{l}\text { ülesande seisukohast olulise ja } \\
\text { ebaolulise info eristamisega tekstis. }\end{array}$ & 2,5 & 12,5 & 15,0 \\
\hline 9) & $\begin{array}{l}\text { autori seisukoha leidmisega tekstist ja } \\
\text { sellele hinnangu andmisega. }\end{array}$ & 1,3 & 8,7 & 10,0 \\
\hline & $\begin{array}{l}\text { tekstidest kiiresti vajaliku info } \\
\text { leidmisega. }\end{array}$ & 0,0 & 7,5 & 7,5 \\
\hline 11) & teksti refereerimisega. & 3,7 & 2,5 & 6,2 \\
\hline 12) & $\begin{array}{l}\text { märkmete tegemisega ülesande } \\
\text { täitmiseks vajaliku info kohta. }\end{array}$ & 1,3 & 3,7 & 5,0 \\
\hline 13) & $\begin{array}{l}\text { teksti detailse lugemisega, et mõista } \\
\text { peamisi mõtteid. }\end{array}$ & 3,7 & 1,3 & 5,0 \\
\hline 14) & $\begin{array}{l}\text { teksti kui terviku mõistmisega: kuidas } \\
\text { kesksed mõtted ja teksti üksikasjad on } \\
\text { omavahel seotud. }\end{array}$ & 1,3 & 2,5 & 3,8 \\
\hline 15) & $\begin{array}{l}\text { tekstist saadud info seostamisel oma } \\
\text { eelnevate teadmistega. }\end{array}$ & 0,0 & 2,5 & 2,5 \\
\hline & $\begin{array}{l}\text { üksikasjaliku loogilise põhjenduse } \\
\text { mõistmisega. }\end{array}$ & 0,0 & 1,3 & 1,3 \\
\hline
\end{tabular}




\title{
The use of reading strategies in academic studies
}

\author{
TIINA KIKERPILL \\ University of Tartu
}

The aim of the study was to ascertain the difficulties students encounter when reading Estonian texts for academic purposes, in order to support them in their studies. 80 native and non-native students from the University of Tartu (Estonia) from 27 programs participated in the study. Data was gathered using a 5-point Likert-type scale questionnaire and analyzed by the following subgroups: L1, L2, BA (years 1-3) and MA (years 4-5).

As regards the reading strategy students used, both L1 and L2 students strategically plan their reading by thinking carefully about the task and using support strategies. Compared to L1 readers, the L2 group more frequently uses different strategies, and they can be characterized as more careful readers on both a local and a global level. Finding out the meaning of unknown words was the most commonly used strategy for both L1 and L2 students, which indicates problems with word recognition processes. However, while L2 readers mostly do so using a dictionary, the L1 readers tend to rely on guessing the meaning using context or background knowledge. Compared to L2 students, L1s tend to be better at expeditious reading.

The top perceived reading difficulties were related to background knowledge (e.g. complicated topic, insufficiency of required knowledge) and vocabulary (struggling with unknown words). In the former, about half of respondents in all subgroups (L1, L2 and years 1 to 5) reported having difficulties. In word recognition, the difficulties were experienced more often by $\mathrm{L} 2$ students and BA students.

The results suggest that, in addition to Estonian language courses for academic purposes, more attention should be paid to developing students' academic reading skills in various specialised courses by providing the background knowledge needed to understand texts and supporting them in interpreting complicated texts. 
TIINA KIKERPILL

Keywords: reading skills; reading comprehension; metacognition; reading strategies; academic reading; second language; Estonian

Tiina Kikerpill

Tartu Ülikooli rakenduslingvistika osakond

Jakobi 2-436, 51014 Tartu, Estonia

Tiina.Kikerpill@ut.ee 